DOI: https://doi.org/10.31933/jemsi.v2i4

Received: 29Maret 2021, Revised: 5 April 2021, Publish: 30 April 2021

\begin{tabular}{|c|c|c|}
\hline DINASTI I & $\begin{array}{l}\text { JURNAL EKONOMI MANAJEMEN } \\
\text { SISTEM INFORMASI }\end{array}$ & $\begin{array}{r}\text { https://dinastirev } \\
\text { editor@din } \\
0811\end{array}$ \\
\hline
\end{tabular}

\title{
PERAN MULTIMEDIA DALAM PERKULIAHAN E-LEARNING: KAJIAN PENERAPANDALAM PROSES PEMBELAJARAN DI PERGURUAN TINGGI
}

\author{
Islahulben Islahulben ${ }^{1)}$, C. Catur Widayati2) \\ ${ }^{1)}$ Fakultas Ekonomi dan Bisnis Universitas Mercu Buana, islahulben@ gmail.com \\ ${ }^{2)}$ Fakultas Ekonomi dan Bisnis Universitas Mercu Buana, christinewijaya73@yahoo.co.id
}

Korespondensi Penulis: christinewijaya73@yahoo.co.id

\begin{abstract}
Abstrak: Konsep yang terkenal dengan sebutan e-Learning ini membawa pengaruh terjadinya proses transformasi pendidikan konvensional ke dalam bentuk digital, baik secara isi (contents) dan sistemnya. Saat ini konsep e-Learning sudah banyak diterima oleh masyarakat dunia, terbukti dengan maraknya implementasi e-Learning di Perguruan Tinggi. e-Learning memungkinkan dosen dan mahasiswa untuk mengakses informasi yang akurat dan up-to-date tanpa hambatan ruang dan waktu. Kemudahan mengakses e-Learning membuat dosen dan mahasiswa dapat belajar dari mana saja dan kapan saja asal memiliki koneksi internet yang memadai. Kesimpulannya adalah: (1) dosen dapat memberikan model pembelajaran secara daring dengan model yang mudah diterima dan dipahami oleh mahasiswa (2) mahasiswa dapat dengan mudah mengambil matakuliah dimanapun tanpa terbatas lagi pada batasan institusi dan negara; (3) Mahasiswa dapat dengan mudah berguru dan berdiskusi dengan para tenaga ahli atau pakar di bidang yang diminatinya; (4) Materi kuliah bahkan dapat dengan mudah diambil di berbagai penjuru dunia tanpa tergantung pada perguruan tinggi dimana mahasiswa belajar.
\end{abstract}

Kata Kunci: e-Learning, transformasi pendidikan, teknologi, penerapan

\section{PENDAHULUAN}

Pendidikan merupakan suatu proses komunikasi dan informasi dari pendidik kepada peserta didik. Dalam suatu proses pembelajaran, pendidik harus memahami hakikat materi pelajaran yang diajarkannya dan memahami berbagai model pembelajaran yang dapat merangsang kemampuan peserta didik untuk menyerap materi yang disampaikan pendidik (Mutia \& Leonard, 2015).

Pemerintah melalui Kementerian Pendidikan dan Kebudayaan menerbitkan Surat Edaran Nomor 3 Tahun 2020 tentang Pencegahan Covid-19 pada Satuan Pendidikan sebagai antisipasi terhadap penyebaran virus Corona di berbagai sekolah maupun perguruan tinggi. Pandemi COVID-19 telah mengubah tatanan hidup manusia, terutama dalam beraktivitas. 
Banyak kegiatan yang kini dilakukan secara online, salah satunya adalah kegiatan belajar mengajar. Pengurangan bahkan peniadaan kegiatan belajar mengajar di kampus menjadi keputusan yang tepat untuk mencegah transmisi COVID-19.

Skenario mengajar dan belajar perlu disiapkan secara matang dalam sebuah kurikulum pembelajaran yang memang dirancang berbasis internet. Mengimplementasikan pembelajaran berbasis internet bukan berarti sekedar meletakkan materi ajar pada web. Selain materi ajar, skenario pembelajaran perlu disiapkan dengan matang untuk mengundang keterlibatan peserta didik secara aktif dan konstruktif dalam proses belajar mereka. Teknologi baru terutama dalam bidang ICT memiliki peran yang semakin penting dalam pembelajaran. Banyak orang percaya bahwa multimedia akan dapat membawa kita kepada situasi belajar dimana "learning with effort" akan dapat digantikan dengan " learning with .fun". (Elyas, 2018)

Kegiatan perkuliahan e-Learning dilaksanakan dengan beberapa aplikasi yang menyediakan layanan tatap muka berupa audio dan video, seperti Zoom, Skype, Google Meet, Microsoft Teams, dan WhatsApp Group. Kegiatan ini dilakukan dengan tetap memperhatikan keefektifan dan ketercapaian mutu pembelajaran yang telah direncanakan.

Pembelajaran e-Learning menggunakan materi dan rentang waktu yang sesuai dengan kurikulum. Adapun dari segi tempat, pembelajaran e-Learning memiliki keleluasaan waktu belajar, dapat belajar dimanapun dan kapanpun. Hal ini dikarenakan cukup sulit untuk dapat menerapkan protokol kesehatan di kampus sehingga pembelajaran e-Learning merupakan alternatif yang cukup baik saat pandemi seperti ini.

Pembelajaran e-Learning memberikan manfaat bagi dosen maupun mahasiswa. Bagi mahasiswa, pembelajaran e-Learning menjadi salah satu metode alternatif belajar yang tidak mengharuskan mereka untuk hadir di kelas. Selain itu, pembelajaran ini akan membentuk jiwa kemandirian belajar, dan juga mendorong interaksi antar mahasiswa, terutama untuk mahasiswa yang biasanya tidak aktif berbicara maka akan dapat lebih leluasa menyampaikan pendapat/pertanyaannya via tulisan jika dilakukan pembelajaran e-Learning seperti saat ini. Sedangkan bagi dosen, metode pembelajaran daring hadir untuk mengubah gaya mengajar konvensional yang nantinya dapat meningkatkan profesionalitas kerja. Model pembelajaran e-Learning juga memberi peluang bagi dosen untuk menilai dan mengevaluasi perkembangan pembelajaran setiap mahasiswanya secara lebih efisien karena dapat berinteraksi langsung dan terd apat rekam jejaknya.

Strategi pembelajaran merupakan salah satu faktor yang berpengaruh terhadap pencapaian kompetensi lulusan. Strategi pembelajaran telah mengalami perkembangan yang cukup pesat seiring dengan perkembangan Teknologi Informasi dan Komunikasi (TIK). Salah satu di antaranya adalah e-Learning. e-Learning telah menjadi suatu kebutuhan bagi sivitas akademika, mengingat baik Dosen, Mahasiswa maupun institusi pendidikan telah memanfaatkan teknologi komputer dalam proses kegiatan belajar-mengajar. e-Learning (Electronic Learning), proses pembelajaran dengan menggabungkan prinsip - prinsip dalam proses pembelajaran dengan teknologi. Perangkat elektronik yang dimaksud dalam hal ini adalah perangkat elektronik yang ada kaitannya dengan Teknologi Informasi dan Komunikasi (TIK) serta multimedia (CD ROM, Video Tape, Televisi, dan Radio). Perkembangan teknologi multimedia telah menjanjikan potensi besar dalam merubah cara seseorang untuk belajar, untuk memperoleh informasi, menyesuaikan informasi dan sebagainya. Multimedia juga menyediakan peluang bagi Dosen untuk mengembangkan teknik pembelajaran sehingga menghasilkan hasil yang maksimal. 
Tujuan dalam penelitian ini adalah: (1) agar mahasiswa dengan multimedia diharapkan mereka akan lebih mudah untuk menentukan dengan apa dan bagaimana mahasiswa untuk dapat menyerap informasi secara cepat dan efisien. (2) Sumber informasi tidak lagi terfokus pada teks dari buku saja melainkan lebih luas dari sumber lain. (3) Kemampuan teknologi multimedia yang telah terhubung internet akan semakin menambah kemudahan dalam mendapatkan informasi yang diharapkan. (4) Sajian audio visual atau lebih dikenal dengan sebutan multimedia menjadikan visualisasi lebih menarik.

\section{KAJIAN LITERATUR \\ Pengertian E-Learning}

Dalam penelitian Mutia \& Leonard, (2015), e-learning berasal dari perpadanan dua kata yakni „,ee dan ,learningee. „e $\mathrm{e}^{e e}$ merupakan singkatan dari electronic dan learning adalah pembelajaran. Jadi E-learning secara harfiah dapat diartikan sebagai pembelajaran yang menggunakan media elektronik, khususnya perangkat komputer. Istilah E-learning mengandung pengertian yang sangat luas, sehingga banyak pakar yang menguraikan tentang definisi E-learning dari berbagai sudut pandang.

Tafiardi (2005:87) mendefiniskan "E-learning sebagai pembelajaran dengan menggunakan jasa bantuan perangkat elektronika". Fokus utama adalah proses belajarnya (learning) bukan pada "e" (electronic), karena perangkat elektronik hanya berperan sebagai alat bantu saja. Peterson (Learnframe, 2000:6) menjelaskan bahwa: "define the e in Elearning from the perspective of the user is exploration, experience, engagement, ease of use, and empowerment". Secara sederhana, Horton (2010:1) mendefinisikan "E-learning is the use of information and computer technologies to create learning experiences". Pendapat Horton tersebut dapat diartikan E-learning sebagai segala bentuk penggunaan informasi dan teknologi komputer untuk menciptakan pengalaman belajar. Definisi ini menekankan bagaimana pengalaman belajar diformulasikan, diorganisir, dan diciptakan melalui perangkat E-learning. Salah satu definisi yang cukup dapat diterima banyak pihak misalnya dari Darin E. Hartley [Hartley, 2001] yang menyatakan "E-learning merupakan suatu jenis belajar mengajar yang memungkinkan tersampaikannya bahan ajar ke siswa dengan menggunakan media Internet, Intranet atau media jaringan komputer lain". LearnFrame.Com dalam Glossary of E-learning Terms (Glossary, 2001; Mutia \& Leonard, 2015) menyatakan suatu definisi yang lebih luas bahwa "E-learning adalah sistem pendidikan yang menggunakan aplikasi elektronik untuk mendukung belajar mengajar dengan media Internet, jaringan komputer, maupun komputer standalone". Dari puluhan atau bahkan ratusan definisi yang muncul dapat kita simpulkan bahwa sistem atau konsep pendidikan yang memanfaatkan teknologi informasi dalam proses belajar mengajar dapat disebut sebagai suatu E-learning.

Menurut (C. Koran 2002 dalam Elyas 2018), mendefinisikan e-learning sebagai sembarang pengajaran dan pembelajaran yang meng-gunakan rangkaian elektronik (LAN, WAN, atau internet) untuk menyampaikan isi pembelajaran, interaksi, atau bimbingan. Ada pula yang menafsirkan e-learning sebagai bentuk pendidikan jarak jauh yang dilakukan melalui media internet. Sedangkan Dong (dalam Kamarga, 2002) mendefinisikan elearning sebagai kegiatan belajar asynchronous melalui perangkat elektronik komputer yang memperoleh bahan belajar yang sesuai dengan kebutuhannya.

Sementara itu Onno W. Purbo (2002 dalam Elyas 2018) mensyaratkan tiga hal yang wajib dipenuhi dalam merancang elearning, yaitu: sederhana, personal, dan cepat. Sistem yang sederhana akan memudahkan peserta didik dalam memanfaatkan teknologi dan menu 
yang ada, dengan kemudahan pada panel yang disediakan, akan mengurangi pengenalan sistem e-learning itu sendiri, sehingga waktu belajar peserta dapat diefisienkan untuk proses belajar itu sendiri dan bukan pada belajar menggunakan sistem e-learningnya. Syarat personal berarti pengajar dapat berinteraksi dengan baik seperti layaknya seorang guru yang berkomunikasi dengan murid di depan kelas. Dengan pendekatan dan interaksi yang lebih personal, peserta didik diperhatikan kemajuannya, serta dibantu segala persoalan yang dihadapinya. Hal ini akan membuat peserta didik betah berlamalama di depan layar komputernya. Kemudian layanan ini ditunjang dengan kecepatan, respon yang cepat terhadap keluhan dan kebutuhan peserta didik lainnya. Dengan demikian perbaikan pembelajaran dapat dilakukan secepat mungkin oleh pengajar atau pengelola.

\section{Hasil Riset tentang Peranan Multimedia dalam Pembelajaran}

Ketika mendengar istilah pembelajaran dengan multimedia, maka yang terlintas di benak penulis adalah penggunaan teknologi presentasi di dalam kelas, misalnya penggunaan televisi, komputer, dan proyektor di dalam kelas. Apakah sebenarnya yang dimaksud dengan multimedia? Multimedia merupakan penggabungan lebih dari satu media menjadi suatu bentuk komunikasi yang bersifat multimodal atau multichannel (Heinich, 2002; Boyle, 1997; Rieber, 1994). Multimedia telah banyak digunakan oleh perusahaan-perusahaan untuk menyampaikan bahan-bahan pelatihan kepada para karyawannya, juga oleh para guru dan dosen untuk menyampaikan materi ajarnya kepada para siswa dan mahasiswa. Diyakini bahwa penggunaan multimedia dalam suatu kegiatan belajar (di sekolah maupun dalam kegiatan pelatihan) mampu meningkatkan hasil kegiatan belajar. Edukasi berupa pemberian informasi akan semakin mudah terekam apabila disampaikan dengan merangsang berbagai indera manusia seperti pendengaran, perabaan dan penglihatan. Salah satunya yang sedang populer adalah media elektronik. Cara ini dapat dimanfaatkan untuk mempermudah menangkap suatu informasi. Software-software presentasi seperti Microsoft PowerPoint menggabungkan berbagai jenis media ke dalam suatu paket presentasi yang menarik, yang akan menarik perhatian dan meningkatkan motivasi para pembelajar (Jonassen dkk, 1999; (Handayani \& Ristrini, 2010).

Hasil-hasil penelitian tentang multiple channel, yaitu tentang penyampaian informasi melalui berbagai jenis media mengindikasikan bahwa ketika suatu channel bersifat melengkapi informasi yang ada (complementary), maka kegiatan belajar akan meningkat, tetapi ketika informasi yang diberikan melalui suatu channel yang berbeda bersifat perulangan yang berlebihan (redundant), maka umumnya kegiatan belajar tidak akan meningkat. Ketika informasi yang diberikan melalui channel yang berbeda tidak konsisten dengan informasi yang telah ada sebelumnya, maka justru akan terjadi penurunan kegiatan belajar (Jonassen, dkk, 1999; Hede, 2002).

Riset tentang multimedia dan teknologi pembelajaran yang berkaitan dengan multimedia selama bertahun-tahun menunjukkan penemuan yang tidak konsisten mengenai efek multimedia terhadap kegiatan belajar. Beberapa riset menunjukkan efek yang positif dari multimedia, sementara yang lain menunjukkan ketiadaan efek, dan bahkan ada yang menunjukkan efek negatif. Ketidakkonsistenan hasil riset ini disebabkan oleh banyaknya faktor-faktor yang menyatu yang mempengaruhi peranan multimedia terhadap kegiatan belajar (Hede, 2002). 
Perdebatan mengenai peran multimedia dalam kegiatan belajar berlangsung sengit antara Robert B. Kozma dan Richard E. Clark. Clark (Clark, 1994) berpendapat bahwa media tidak berpengaruh terhadap kegiatan belajar. Menurutnya, media hanya merupakan "kendaraan" untuk kegiatan belajar, sedangkan yang berpengaruh terhadap kegiatan belajar adalah metode yang digunakan. Clark setuju dengan pendapat bahwa media baru yang digunakan dalam kegiatan belajar akan berpengaruh terhadap kegiatan belajar seorang pembelajar, tetapi begitu pembelajar tersebut sudah terbiasa dengan media baru itu, maka pengaruh dari media tersebut sudah tidak ada lagi.

Kozma (Kozma, 1991, 1994) berpendapat bahwa media dapat meningkatkan kegiatan belajar. Media dapat membantu membuat "model mental" yang lebih baik sehingga membantu pemahaman seorang pembelajar. Sebagai contoh, sebuah buku yang berisi teks saja mensyaratkan kita untuk memiliki pengetahuan awal tentang apa yang dibahas di dalam buku tersebut supaya kita bisa membuat "model mental". Tanpa pengetahuan awal (prior knowledge) tentang materi yang dibahas, "model mental" yang dibuat bisa jadi tidak akurat. Ketika pada buku tersebut juga disertakan gambar, maka pembelajar akan lebih mudah membuat "model mental" yang lebih lengkap dan tepat. Dengan demikian, melalui media, seorang pembelajar memiliki kemampuan untuk menjelajahi tempat-tempat, di dalam dunia virtualnya, yang mungkin tidak akan pernah dilihatnya secara langsung. Artinya, media meningkatkan kemampuan manusia untuk belajar.

Berdasarkan perdebatan mengenai peranan multimedia dalam pembelajaran tersebut, dapat ditarik beberapa kesimpulan sebagai berikut:

a) Multimedia dapat digunakan untuk membantu pembelajar membentuk "model mental" yang akan memudahkannya memahami suatu konsep.

b) Pemanfaatan multimedia dapat membangkitkan motivasi belajar para pembelajar, karena adanya multimedia membuat presentasi pembelajaran menjadi lebih menarik.

c) Perlu diperhatikan juga bahwa "sesuatu yang menarik tidak secara otomatis mudah dipahami", karena adakalanya, suatu tampilan yang menarik justru akan memecah fokus perhatian pembelajar. Penggunaan multimedia harus benar-benar dipilih sesuai kebutuhan. Ada beberapa materi pembelajaran (terutama yang kompleks) yang memerlukan multimedia, tetapi ada juga materi pembelajaran yang cukup disampaikan secara lisan saja, tanpa perlu bantuan perangkat multimedia karena cukup sederhananya materi tersebut.

\section{METODE}

Metode Penelitian yang digunakan dalam penelitian ini adalah penelitian kepustakaan (library research).

\section{PEMBAHASAN}

\section{Peranan Multimedia Dalam Perkuliahan e-Learning}

E-learning, seperti juga namanya "Electronic Learning" disampaikan dengan menggunakan media elektronik yang terhubung dengan Internet (World Wide Web yang menghubungkan semua unit komputer di seluruh dunia yang terkoneksi dengan Internet) dan Intranet (jaringan yang bisa menghubungkan semua unit komputer dalam sebuah perusahaan). Jika Anda memiliki komputer yang terkoneksi dengan Internet, Anda sudah bisa 
berpartisipasi dalam elearning. Dengan cara ini, jumlah pembelajar yang bisa ikut berpartisipasi bisa jauh lebih besar dari pada cara belajar secara konvensional di ruang kelas (jumlah siswa tidak terbatas pada besarnya ruang kelas).

Tidak dapat dipungkiri, menciptakan kegitatan belajar mengajar yang menarik masih menjadi masalah bagi hampir sebagian besar Dosen. Berbagai upaya dalam rangka menjawab permasalahan ini telah dirumuskan oleh berbagai pihak. Daya tarik perkembangan teknologi serta gaya Mahasiswa masa kini yang lebih update pada teknologi harus diimbangi oleh Dosen, sehingga perkuliahan e-Learning lebih menarik perhatian Mahasiswa untuk dapat mengikuti perkulahan e-Learning dengan baik. Berdasarkan pengalaman penulis selama mengajar di perguruan tinggi dengan sistem perkuliahan e-Learning selama 12 tahun mendapatkan kesan menarik untuk mengikuti perkuliahan oleh Mahasiswa adalah langkah awal yang penting dan menentukan bagi pencapaian tujuan pembelajaran yang diharapkan.

Menurut penulis banyak hal mengenai kelebihan dan kelemahan dari sistem perkuliahan e-Learning yang telah penulis alami. Beberapa kelemahan dari sistem perkuliahan e-Learning diantaranya kejenuhan Mahasiswa dan Dosen, oleh karena itu perlu dilakukan tatap maya via Zoom atau GoogleMeet minimal 3 x dalam satu semester. Mengenai kelebihannya adalah adanya fasilitas multi media berupa gambar, teks, animasi, suara dan video. Kelebihan tersebut sejalan dengan hasil penelitian yang dilakukan oleh Prof Albert Mehrabian tentang bagaimana audience dapat menerima informasi dengan baik pada suatu presentasi. Hasil penelitiannya menyimpulkan bahwa 55\% informasi yang kita terima dalam bentuk visual, sedangkan vocal $38 \%$ dan hanya $7 \%$ dalam bentuk teks.

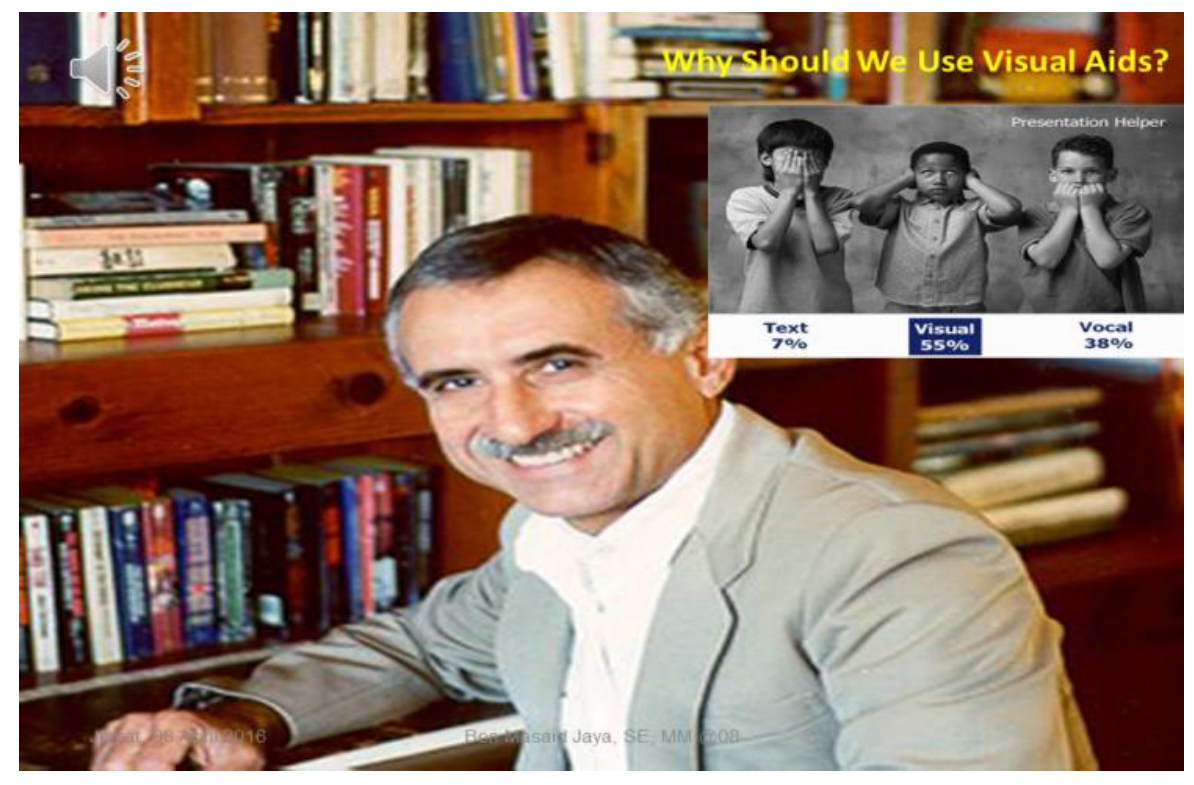

Source: http://www.presentationhelper.co.uk/Essential_Presentation_skills.htm

A research by Professor Albert Mehrabian on how we take in information during a presentation: $55 \%$ of the information we take in is visual and only $7 \%$ is text.

Artinya, audience lebih mudah menerima informasi jika disampaikan dalam bentuk $\operatorname{visual}(55 \%)$ dan $\operatorname{Vocal}(38 \%)$. 
Apabila presentasi disampaikan dalam bentuk teks saja akan lebih sulit untuk diterima. Hal ini terjadi karena slide presentasi yang hampir semua berupa teks(tulisan). Hal ini mengakibatkan presenter akan membaca teks dalam penyampaian presentasinya dan audience secara tidak langsung diminta juga untuk membacanya. Presentasi seperti ini akan sangat menjenuhkan dan berakibat tidak adanya perhatian audience pada kita.

Penulis berpendapat bahwa solusi untuk mengatasi suatu presentasi dengan teks yang hanya $7 \%$ adalah dengan cara menggunakan metode Mind Map dari Tony Buzan.

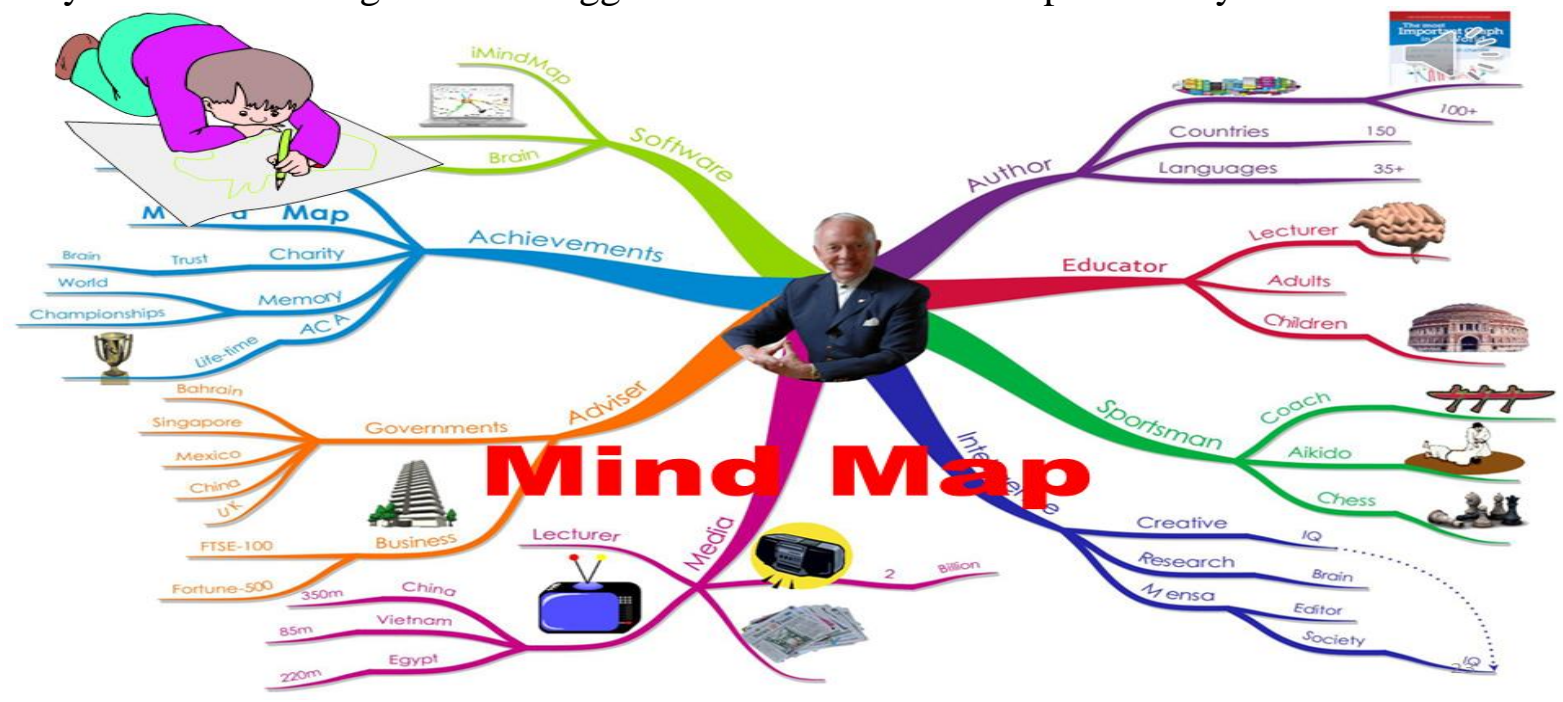

Mind Map adalah suatu teknik berpikir paling efektif paling efektif yang sudah teruji selama lebih dari 40 tahun, ditemukan oleh Tony Buzan pada tahun 1970'an dan bahkan ribuan tahun pada masa lampau sudah digunakan oleh para Genius kreatif besar seperti Leonardo Da Vinci yang menggunakan unsur - unsur utama mind map untuk menjadikan pikiran-pikiran menjadi kasat mata dengan menggunakan bahasa gambar untuk menangkap pikiran - pikiran yang bermunculan di otaknya dan menuangkan ke dalam kertas (Herdin, TLI : XXV).

Menurut Tony Buzan(2008:4), Mind Map adalah cara mengembangkan kegiatan berpikir ke segala arah, menangkap berbagai pikiran dalam berbagai sudut. Mind Map mengembangkan cara berpikir divergen dan kreatif. Mind Map juga disebut juga dengan peta konsep merupakan alat berpikir organisasional yang sangat hebat, ini juga merupakan cara termudah untuk menempatkan informasi dalam otak dan mengambil informasi itu saat dibutuh. Mind Map dapat membantu dalam berbagai hal seperti merencanakan, berkomunikasi, menjadi lebih kreatif, menyelesaikan masalah, memusatkan perhatian, menyusun dan menjelaskan pikiran, mengingat dengan baik, belajar lebih cepat dan efisien serta melatih gambar keseluruhan.

Mind Map juga bisa diartikan sebagai proses memetakan pikiran untuk menghubungkan konsep permasalahan tertentu dari cabang sel saraf membentuk kolerasi konsep menuju suatu pemahaman dan hasilnya dituangkan langsung di atas kertas dengan animasi yang disukai dan mudah dimengerti oleh pembuatnya. Sehingga, tulisan yang dihasilkan merupakan gambaran langsung cara kerja koneksi di dalam otak.

Beberapa hasil penelitian yang pernah dilakukan terhad ap Mind Map (Herdin, TLI: xxvii) :

a) Farrand, Hussain, and Hennessy(202) menemukan bahwa Mind Mapping dapat meningkatkan menori jangka panjang dan dilaporkan sebagai teknik yang baik dalam 
pembelajaran yang efektif ketika dipakai dalam penulisan materi pelajaran dan meningkatkan daya ingat.

b) Goodnough and Woods (2002) meneukan bahwa siswa merasakan Mind Map sebagai sesuatu yang menyenangkan, menarik, dan meotivasi untuk belajar. Karena terdapat pilihan warna, simbol, dan hanya menggunakan Kata Kunci.

c) Budd (2004) membuktikan bahwa Mind Mapping menarik siswa untuk belajar dengan pembelajaran aktif. Khususnya agar siswa memperoleh nilai tinggi dengan menggunakan Mind Map.

d) Cunningham (2005) menghasilkan bahwa 80\% dari siswa menyatakan "Mind Mapping telah membantu mereka mengerti konsep dan ide dalam mempelajari ilmu pengetahuan di sekolah".

e) Wickramisinghe et al (2007) menemukan menemukan bahwa kebanyakan siswa kedokteran ketika menggunakan Mind Mapping sangat membantu dalam menginat informasi yang terorganisasi dibandingkan dengan teknik pembelajaran yang sering dilakukan terdahulu.

f) Penelitian yang dilakukan TOI (2009) menujukkan bahwa Mind Map dapat membantu anak mengingat kembali kata-kata dengan lebih efektif dibandingkan dibuat dalam bentuk daftar dengan peningkatan memori $>32 \%$.

Ada sejumlah manfaat yang dapat dirasakan melalui Mind Map (Herdin :xxii) :

a) Mind Map cara hebat membuat catatan sekolah. Mind Map membantu kita untuk mencatat informasi-informasi penting yang didapat melalui KATA KUNCI. Mind Map juga membantu untuk membuat hubungan diantara fakta dan beragam dalam 1 kertas saja.

b) Mind Map meningkatkan Daya ingat. Proses membuat Mind Map melibatkan gabungan yang unik dari imajinasi, warna, dan visualisasi yang terbukti dapat menginagt lebih lama dibandingkan dengan metode mencatat biasa dan belajar dengan menghafal.

c) Mind Map membantu Meningkatakan Kreativitas. Mind Map benar - benar dirancang untuk membangkitkan kreativitas dan memunkinkan anak menghasilkan karya yang unik dari kecerdasan dan latihan pikiran. Mind Map membantu anak untuk menghasilkan gambaran yang lebih baik dan membuat hubungan baru lebih terlihat sehingga anak dapat membuat sesuatu yang tidak terbatas dari pikiran, ide, hubungan dan asoiasi dari topik tertentu.

d) Mind Map cara terbaik membuat karangan singkat. Saat anak diminta guru membuat karangan singkat sebagian besar anak akan merasa sulit dan membosankan. Dengan Mind Map, anak akan menghasilkan lebih banyak ide dengan cepat serta dengan mudah dapat melihat kaitan diantara topik dengan paragraf utama yang ada

e) Mind Map cara mudah belajar saat menghadapi ujian. Pada saat menghadapi ujian kita sering merasa takut dan stres. Apalagi harus membaca tumpukan catatan atau buku. Hal ini membuat anak merasa jenuh dan tidak lagi semangat untuk belajar. Solusi masalah ini adalah ah dengan Mind Map karena Mind Map membuat pengulangan pembelajaran menjadi sederhana karena didalamnya terdiri dari kata kunci yang saling berkaitan dari setiap bab 
f) Mind Map meningkatkan rasa percaya diri anak didik. Mind Map sangat efektif digunakan untuk meningkatkan rasa percaya diri sebelum dan sesudah memulai suatu pembelajaran, serta pada saat menghadapi presentasi. Mind Map membuat anak lebih siap, santai dan percaya diri.

g) Mind Map sangat efektif untuk menggali ide. Mind Map sangat efektif digunakan pada saat belajar, diskusi, dan interview. Maind Map menjadikan pikiran-pikiran kasat mata dengan menggunakan bahasa gambar untuk menangkap pikiran-pikiran yang bermunculan di otak dapat menggali ide lebih detil tanpa batas. membuat belajar lebih menyenangkan sistematis dan efektif.

h) Mind Map sangat powerfull untuk memecahkan masalah dan membuat keputusan yang tepat. Mind Map sangat powerful digunakan pada saat kita ingin memecahkan suatu masalah yang ada. Mind Map menjadikan kita tahu lebih banyak tentang apa yang sedang kita pikirkan dan pertimbangkan. Dengan menggunakan pola pikir yang tepat dan menggali ide lebih detil tentang masalah apa yang kita pertimbangkan.Membuat kita mengerti betul masalah yang ada dan merasakan itu lebih baik dan menyenangkan sehingga kita dapat mengambil suatu keputusan yang tepat.
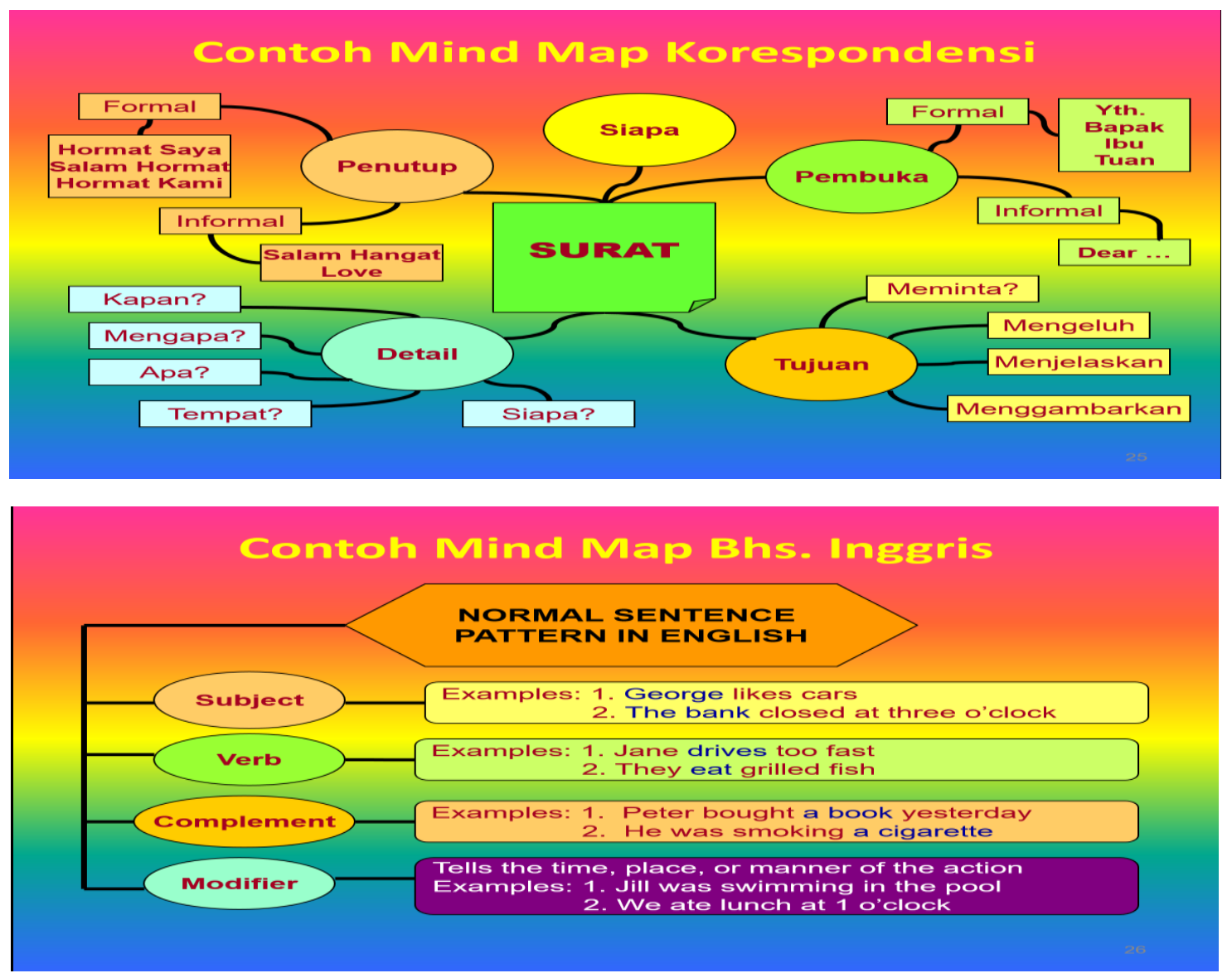

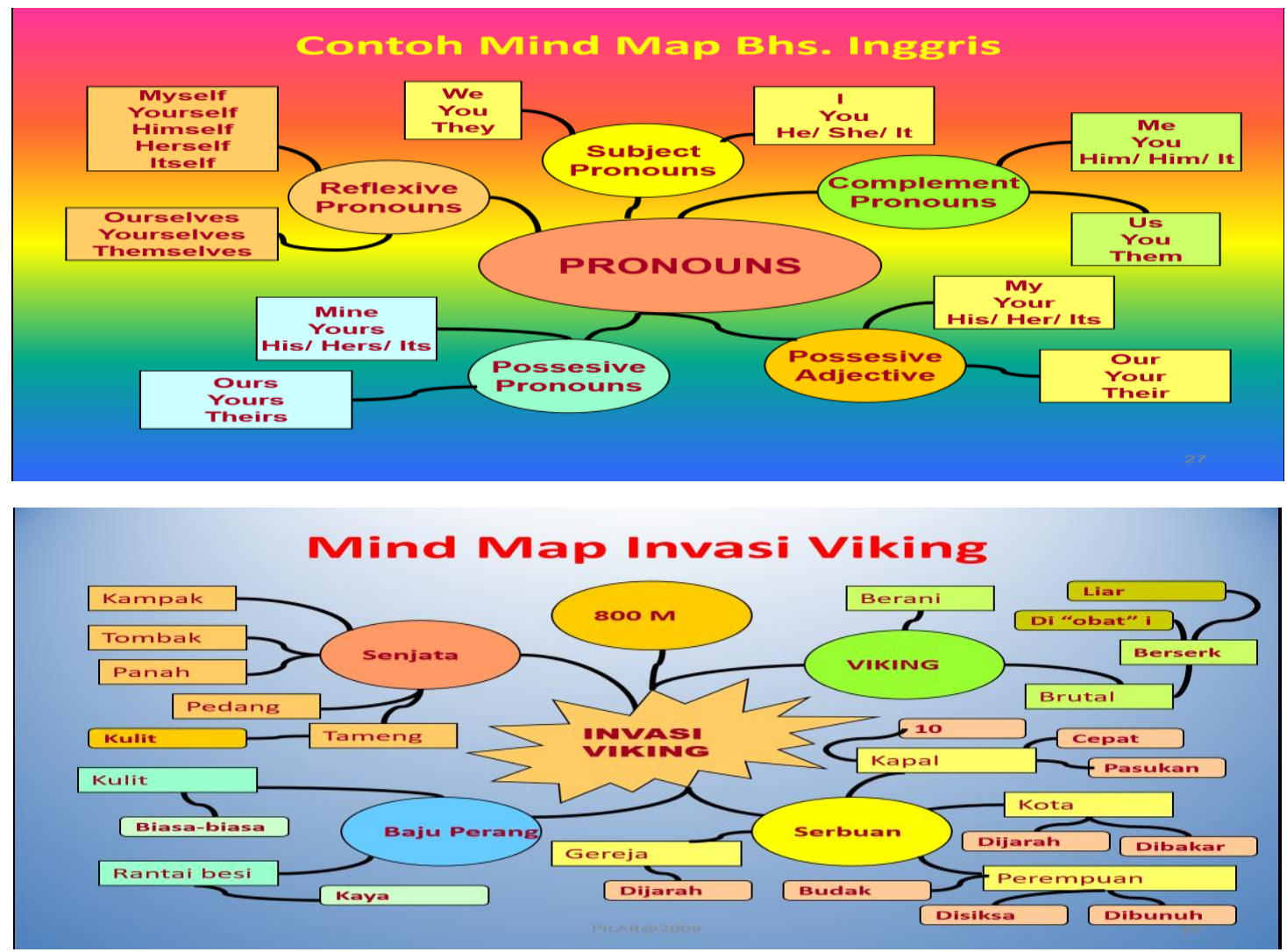

Dari beberapa pemaparan di atas, penulis dapat mengambil kesimpulan bahwa inti dari Mind Map yang dapat digunakan dalam perkuliahan e-Learning adalah dengan memanfaatkan kata kunci yang sudah dibuat dalam Mind Map.

\section{Cara Membuat Mind Map}

Mind Map merupakan alat berpikir kreatif yang mencerminkan cara kerja otak secara alami. Mind map ini memungkinkan otak untuk menggunakan semua gambar dan asosiasi dalam pola radial dan jaringan sebagaimana otak dirancang.

Langkah - Langkah yang perlu dilakukan meringkas buku dengan Mind Map

a) Tentukan topik utama sebagai Tema

b) Tentukan sub topik sebagai ranting

c) Secara kreatif gunakan gambar, simbol, kode, dan dimensi seluruh peta pikiran.

d) Sdapat mungkin gunakan kata kunci tunggal, maksimal dua kata dengan huruf kapital atau kecil

e) Gunakan garis lengkung antara topik sentral dengan topik utama dan sub topik

f) Terus tambah sub akar temanya

g) Tambahkan beberapa gambar yang mudah atau beberapa icon bentuk lainnya dan warna juga

\section{https://www.youtube.com/watch?v=EthL6nG2IIE}




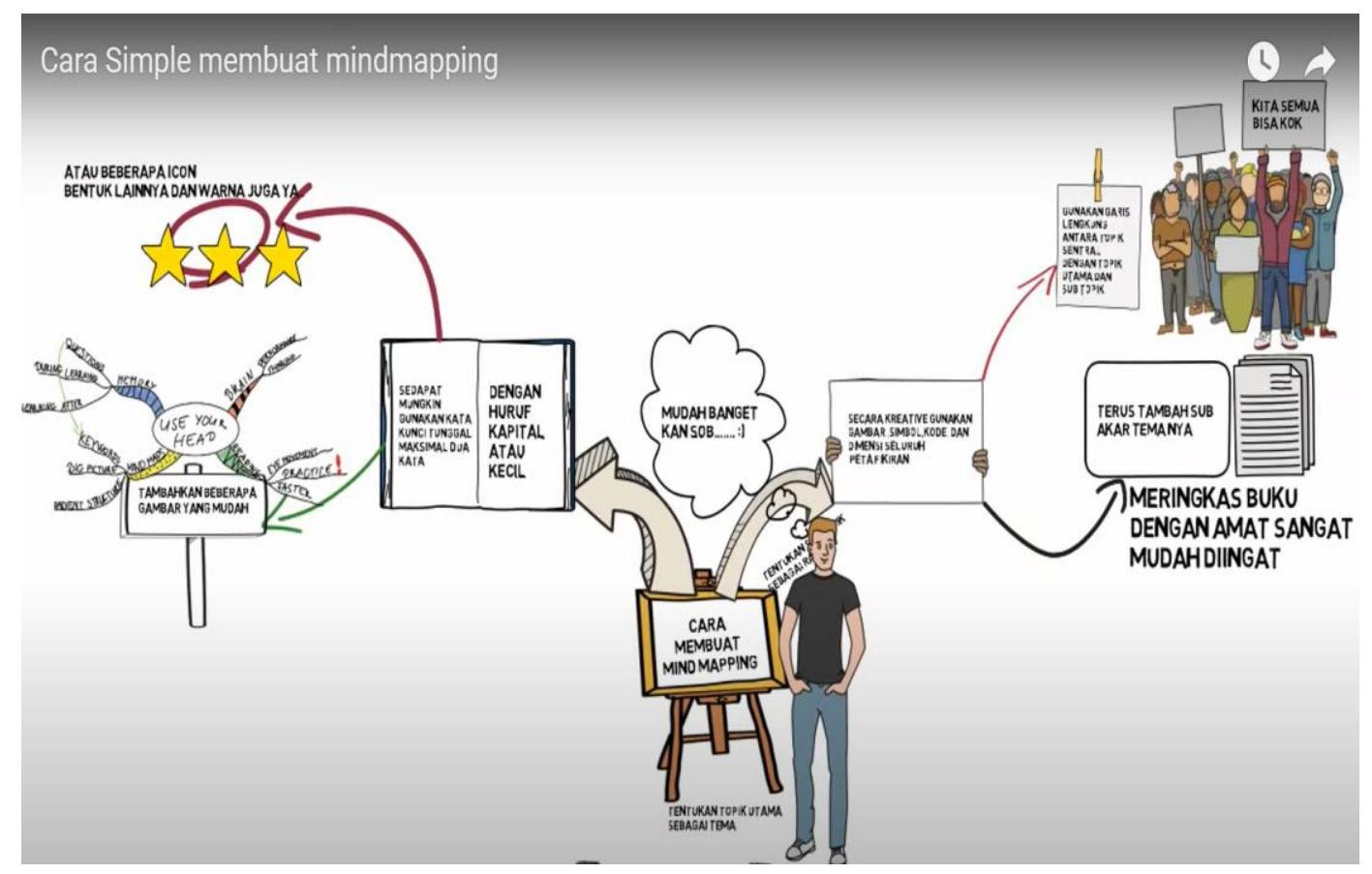

Dalam pembuatan Mind Map dapat dilakukan secara online, tanpa install software dengan mengunjungi website :

\section{https://drive.mind mup.com/map/1uzlN0oYjX1GI2FWyT_CTB06G7exLw1V1}

Sistem pembelajaran e-Learning menyediakan fasilitas Multi Media dalam web nya, pengajar dapat memanfaatkan fasilitas multi media tersebut dalam pembuatan konten pembelajarannya, sebagai contoh tampilan visual dari kelas yang diampu dan pembuatan slide presentasi (Power Point) mulimedia.

Tampilan visual dari kelas e-Learning dapat dilakukan dengan mengupload gambar, video sesuai dengan materi perkuliahan e-Learning nya.

Contoh tampilan multimedia: 

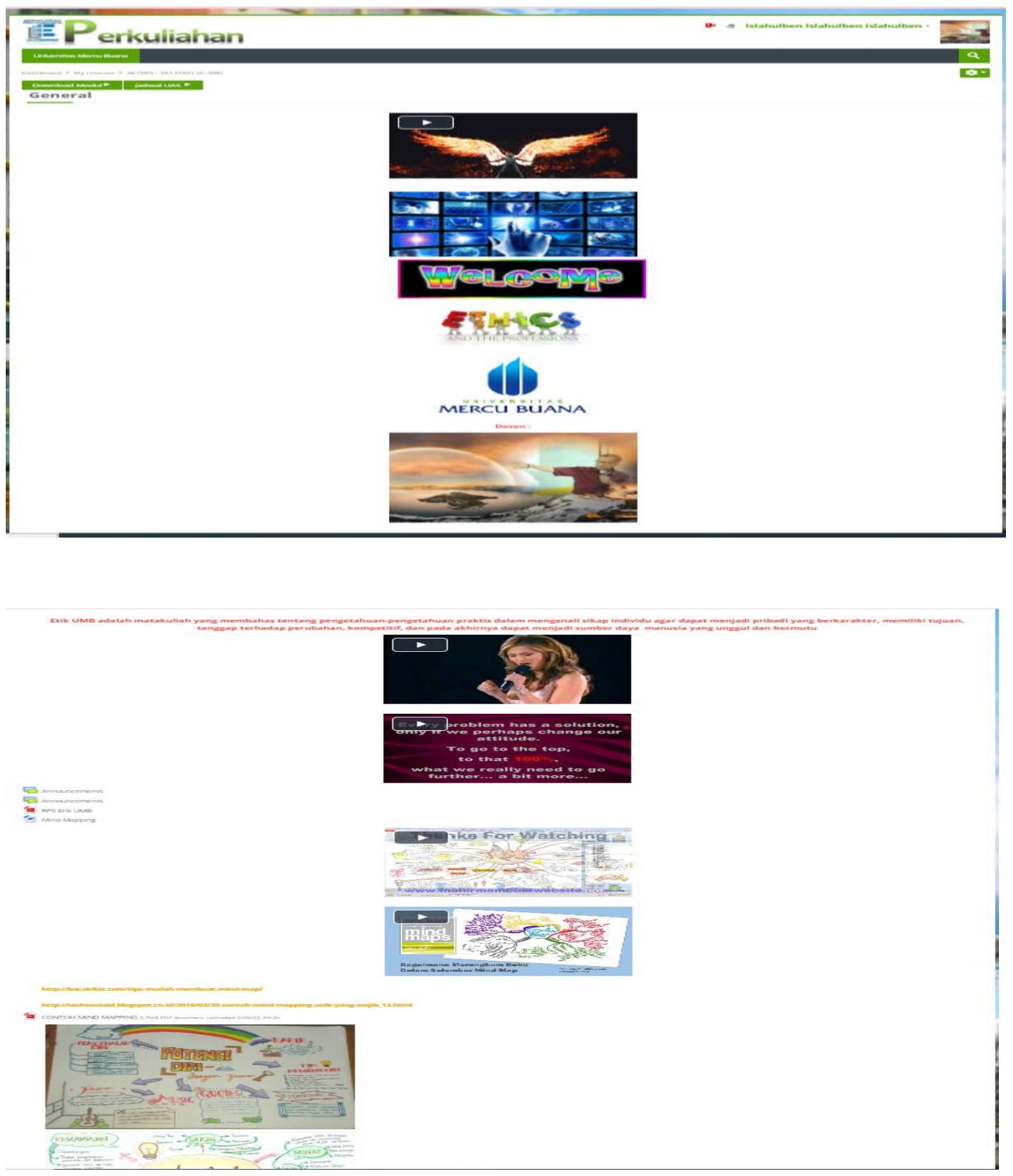


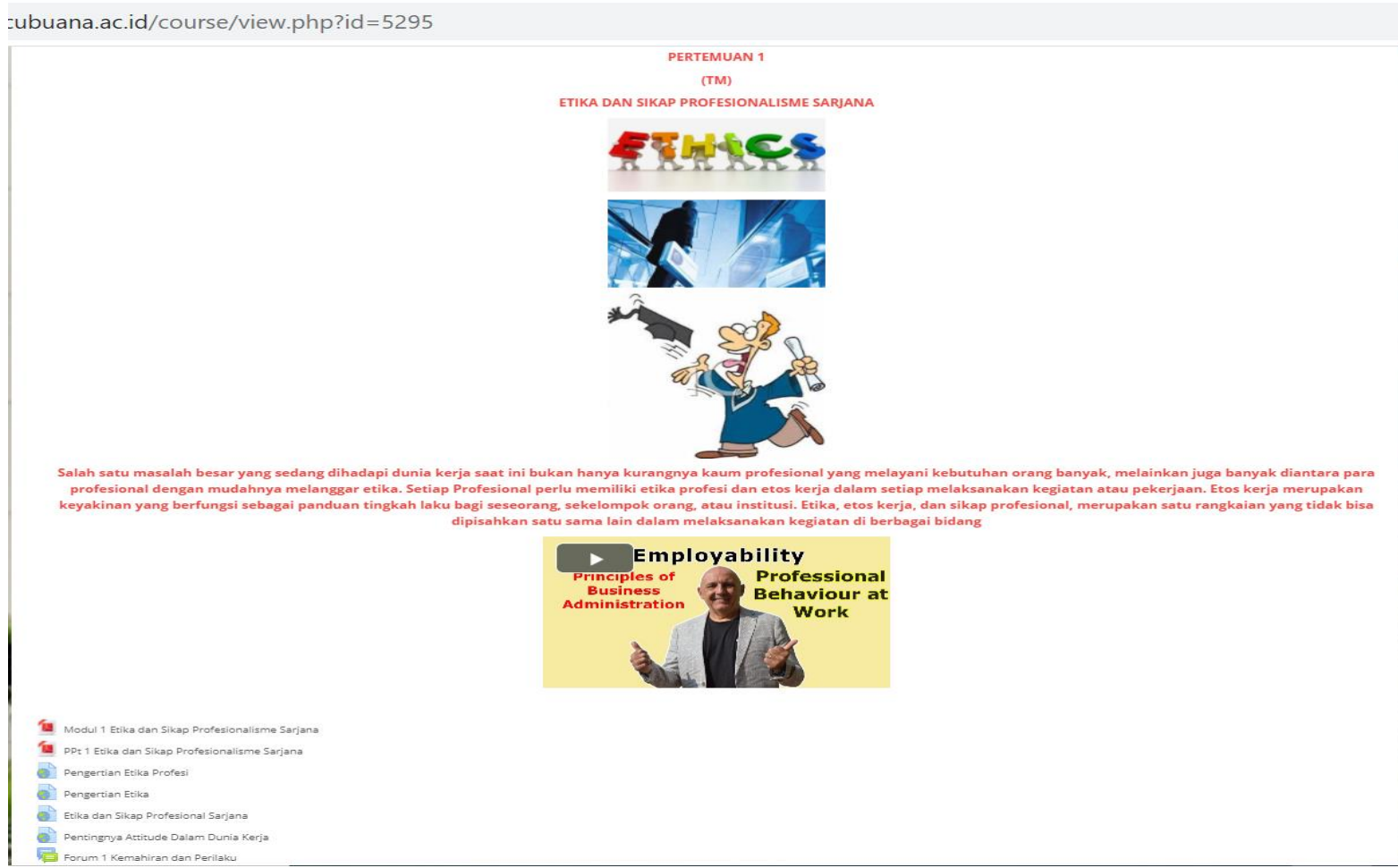

Tampilan multimedia dari forum diskusi :

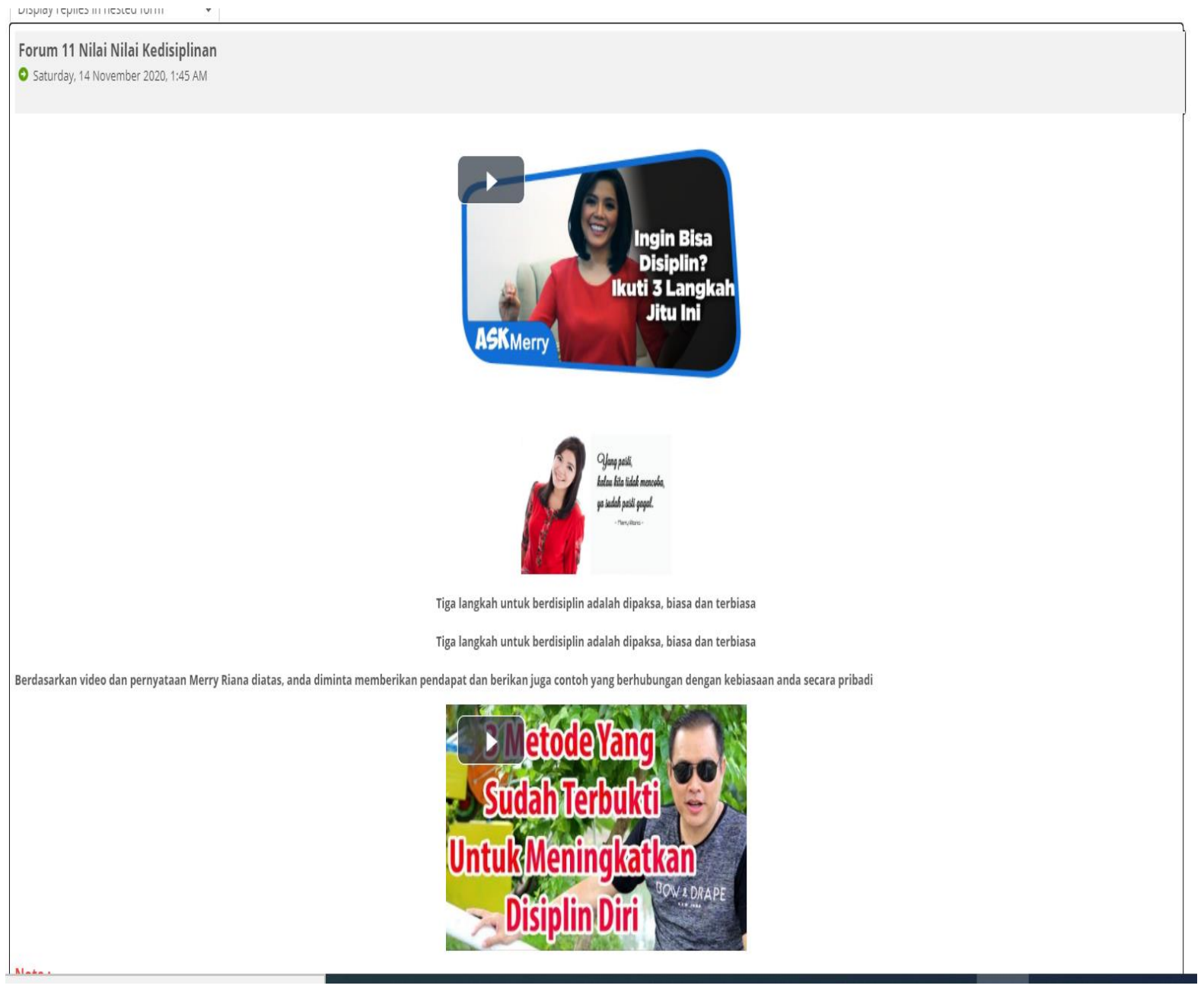




\section{Slide Presentasi Power Point Multimedia secara visual}

Langkah pertama yang perlu dilakukan adalah membuat Kata Kunci dari modul materi perkuliahan setiap slide nya dan penjelasan materi/narasi nya dengan menggunakan Vocal/Audio disertai dengan menampilkan gambar yang sesuai dengan narasi dari setiap slide.

Materi Power Point Multimedia yang mengandung unsur Video, Audio dan Gambar, selanjutnya materi Power Point tersebut dibuat menjadi visual dengan menjadikan file nya menjadi video(MPEG-4 Video). Selanjutnya video tersebut di upload pad a Chanel Youtube Contoh Link Youtube nya :

https://www.youtube.com/watch?v=wScw4IxYc8Q\&t=72s

'每 Modul 11 Nilai - Nilai Kedisiplinan dan Tanggung Jawab 1004.1KB PDF document Uploaded 109120, 07:53

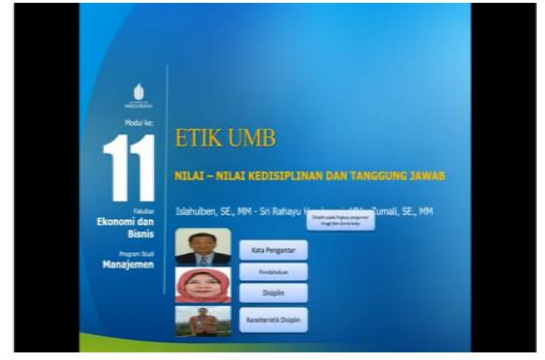

'́l PPt 11 Nilai - Nilai Kedisiplinan dan Tanggung Jawab 2.9MB PDF document Uploaded 16105/20,06:58

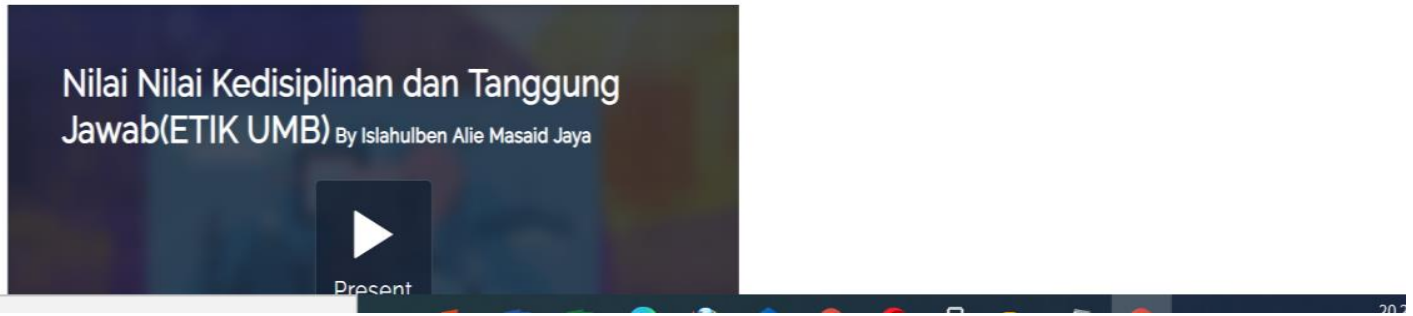

'ú Modul 11 Nilai - Nilai Kedisiplinan dan Tanggung Jawab 1004.1KB PDF document Uploaded 10920,07:53

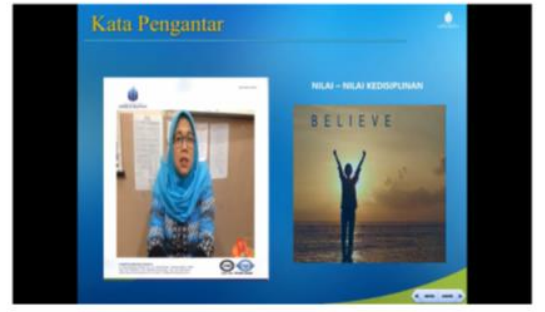

囟 PPt 11 Nilai - Nilai Kedisiplinan dan Tanggung Jawab 29.9B PDF document Uploaded 16/05/20,06:58

Nilai Nilai Kedisiplinan dan Tanggung

Jawab(ETIK UMB) By Islahulben Alie Masaid Jaya 


\section{Keunggulan dan Kekurangan Multimedia Dalam Perkuliahan e-Learning}

Pengajar dalam melaksanakan perkuliahan e-Learning sebaiknya menggunakan media yang lengkap, sesuai dengan keperluan dan menyentuh berbagai indra. Dalam memenuhi pelaksanaan perkuliahan e-Learning yang efektif adalah dengan menggunakan Multimedia sebagai salah satu alternatif pilihan yang baik untuk pengajaran dan pembelajaran yang berkesan. Perkuliahan e-Learning berbasis Multimedia melibatkan hampir semua unsur unsur indra manusia dan dapat mempermudah Mahasiswa dalam menerima informasi yang Dosen sampaikan dengan lebih efektif dan efisien. Selain itu perkuliahan dengan menggunakan Multimedia akan sangat meningkatkan motivasi belajar Mahasiswa karena indra mereka dapat dengan mudah menerima informasi yang diberikan sesuai dengan hasil penelitian Prof Albert Mehrabian tentang audience lebih nyaman menerima informasi yang disampaikan secara visual(55\%), Vocal(38\%) dan Text (7\%)

Penggunaan teknologi multimedia dalam perkuliahan e-Learning dapat mengembangkan Computer Assisted Learning (CAL) yaitu perangkat lunak pendidikan yang diakses melalui komputer dan merupakan bentuk pembelajaran yang menempatkan komputer sebagai "dosen" dan proses belajar dapat berlangsung secara individu dan mampu mengadopsi perbedaan individu peserta didik. Karena pada intinya CAL merupakan media ganda yang terintergrasi yang dapat menyajikan suatu paket ajar yang berisi komponen visual dan audio secara bersamaan.

Manfaat komponen Computer Assisted Learning (CAL) antara lain:

a. Teks, efektif untuk menyampaikan informasi verbal, merangsang daya pikir kognitif dan memperjelas media lainnya

b. Audio, efektif untuk memancing perhatian, menumbuhkan daya imajinasi dan menambah atau membentuk suasana jadi hidup

c. Video, efektif untuk memperlihatkan peristiwa masa lalu sesuai kejadian yang sebenarnya, menyajikan peristiwa penting maupun kejadian langka yang sulit didapat, menampilkan gerakan obyek yang terlalu cepat atau lambat menjadi normal sehingga dapat dilihat mata.

Dari pengalaman penulis dalam mengajar perkuliahan e-Learning, ada beberapa kelemahan dari pemanfaatan komponen multimedia antara lain :

a. Mahasiswa malas membuka video yang disajikan dengan berbagai alasan, salah satunya adalah keterbatasan kuota internet dan waktu yang sempit karena mereka disamping sebagai mahasiswa juga bekerja. Mahasiswa hanya membaca pertanyaan/instruksi dari pengajar sehingga jawaban mereka tidak disertai analisa dari video yang ada.

b. Kesulitan dan keterbatasan waktu bagi pengajar untuk mencari video atau gambar yang berhubungan dengan materi yang sedang dibahas.

\section{Model Pembelajaran Mind Map sebagai Virtual Learning Environment}

Penerapan metode Mind Map dalam perkuliahan e-Learning didahului dengan memberikan beberapa aktivitas online (Forum, Quiz, Tugas)

\section{Forum Diskusi}

Forum yang diberikan mengandung unsur Video, Audio dan Gambar. Mahasiswa diminta menganalisanya, jangan berupa pertanyaan. Agar perkuliahan e-Learning nya efektif, hendaknya forum dibuat dengan standar $1 \mathrm{SKS}=1$ Forum Diskusi 
Dalam menjawab forum diskusi, Mahasiswa diminta menjawab dengan menggunakan metode Mind Map artinya mahasiswa menstruktur kan jawaban/pikirannya dengan metode Mind Map

Contoh:

Forum 1 Eye Contact dalam komunikasi efektif

https://www.youtube.com/watch?v=aZmlS7n7Re4

https://www.youtube.com/watch?v=zecUvbGL7xY

https://www.youtube.com/watch?v=Ior3iIXjMTU

Di era Globalisasi saat ini, ketrampilan berkomunikasi secara efektif sangat dibutuhkan.Komunikasi adalah proses dinamis yang dapat mempengaruhi secara positif/negatif dalam bersosialisasi di masyarakat. Salah satu hambatan dalam komunikasi efektif adalah Eye Contact.

Anda diminta memberikan pendapat tentang penting nya Eye Contact dalam komunikasi ! (Pend apat and a disampaikan dengan menggunakan metode Mind Map)

Menurut anda mengapa Eye Contact dapat menghambat komunikasi efektif ? (Jawaban anda disampaikan dengan menggunakan metode Mind Map)

Forum 2 Menyikapi Perubahan
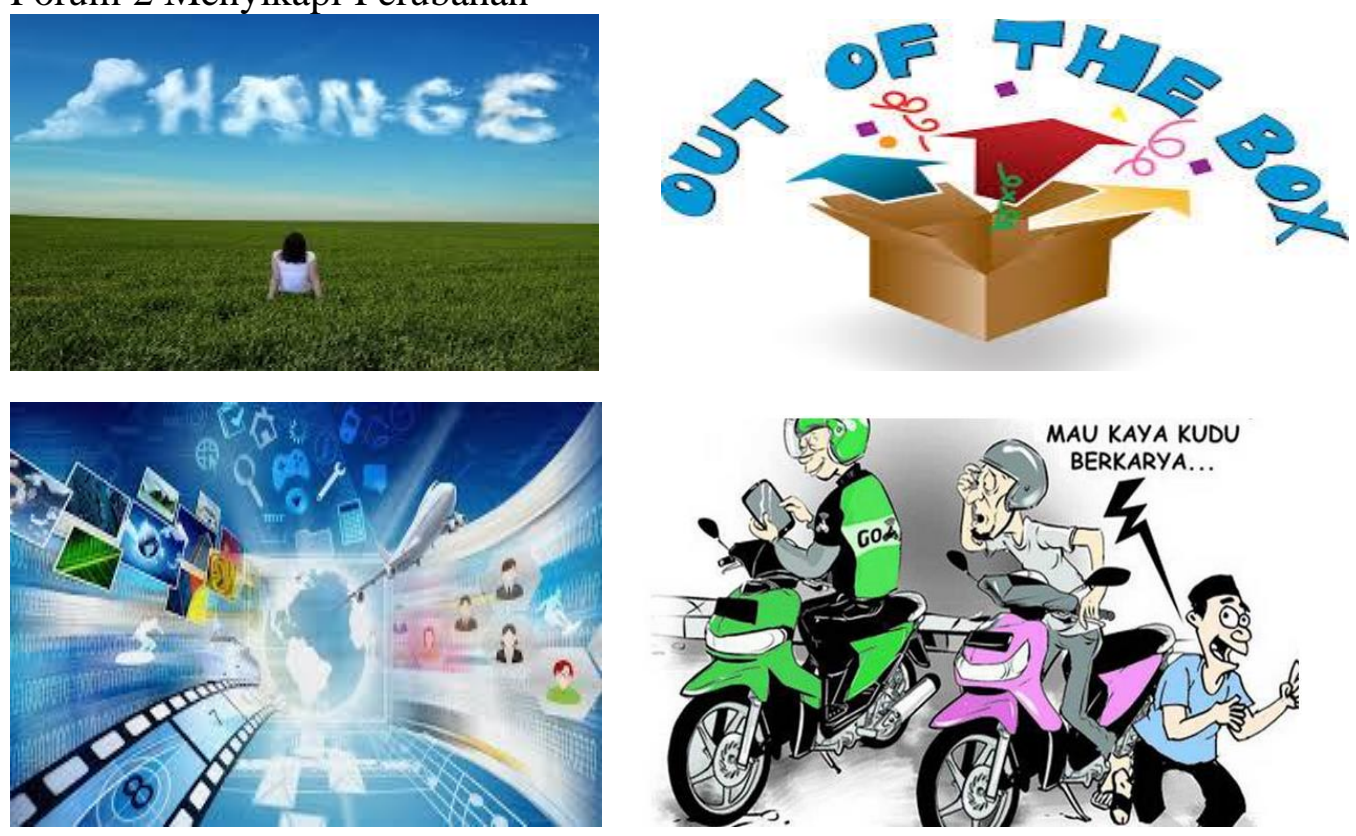

Dari Gambar diatas, Mahasiswa diminta membuat narasi tentang perubahan, Dari Narasi yang sudah dibuat, Mahasiswa diminta membuat Mind Map nya, Anda diminta memberikan pendapat tentang perubahan dengan selalu update teknologi ! (Pendapat anda disampaikan dengan menggunakan metode Mind Map)

\section{Tugas Besar/Assignment}

Tugas besar yang diberikan berupa meringkas artikel, menganalisa jurnal, perencanaan, dan membuat slide presentasi. Mahasiswa diwajibkan mengerjakan tugas besar tersebut dengan menggunakan metode Mind Map.

Meringkas artikel

a) Pengajar upload artikel yang berhubungan dengan materi yang sedang dibahas

b) Mahasiswa membuat ringkasan dengan menggunakan metode Mind Map 


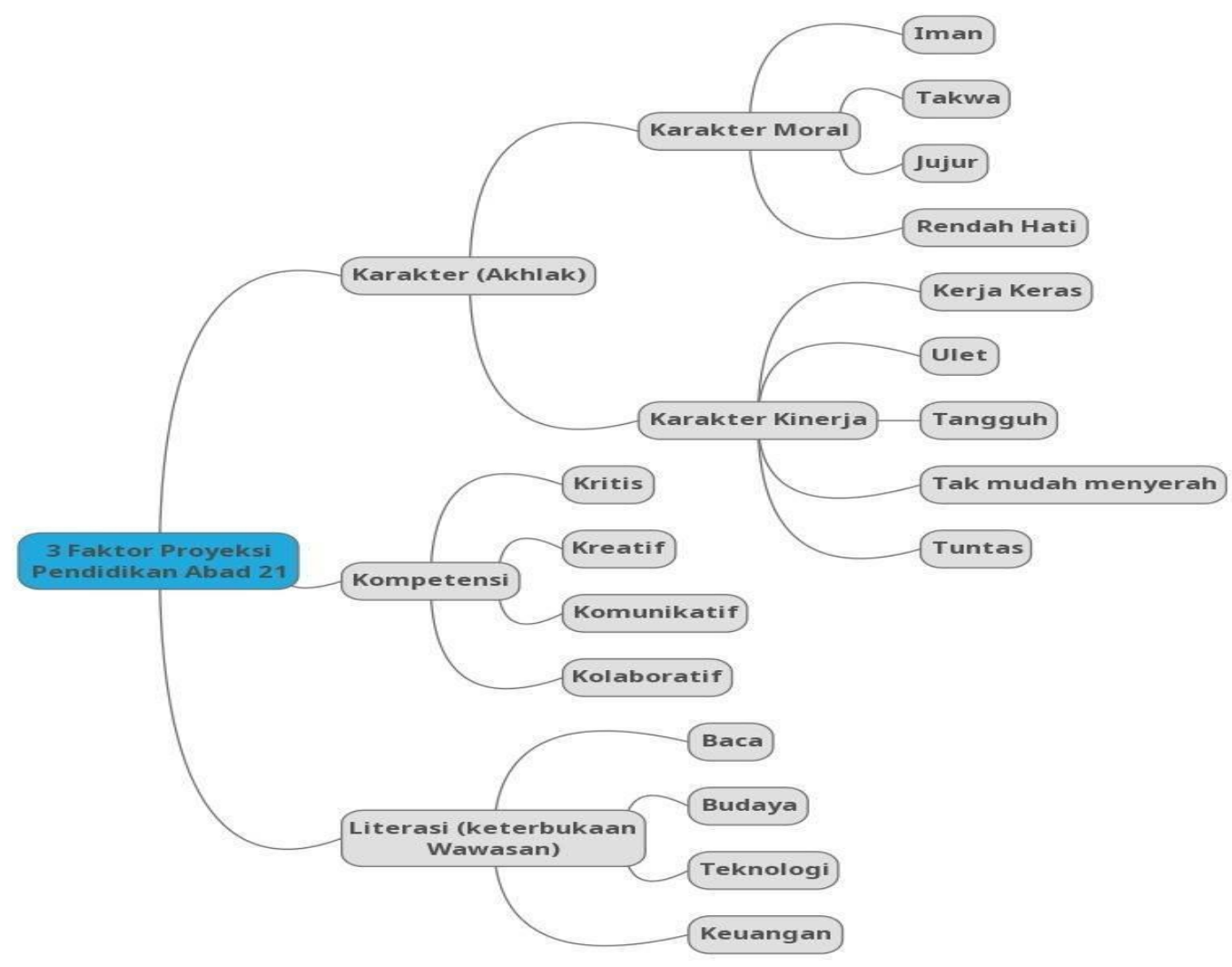

\section{Menganalisa Jurnal}

1) Pengajar upload jurnal yang akan dianalisa

Motivasi berprestasi pada Mahasiswa berprestasi dari keluarga tidak mampu secara

ekonomi

http://journal.unair.ac.id/download-fullpapers-jppp21f8f641abfull.pdf

2) Mahasiswa diminta menyampaikan analisa dan memberikan pendapatnya tentang jurnal tersebut dengan menggunakan metode Mind Map

\section{Perencanaan pengembangan diri}

a) Mahasiswa diminta membuat rencana pengembangan diri mereka

b) Rencana pengembangan diri tersebut dibuat dengan menggunakan metode Mind Map 


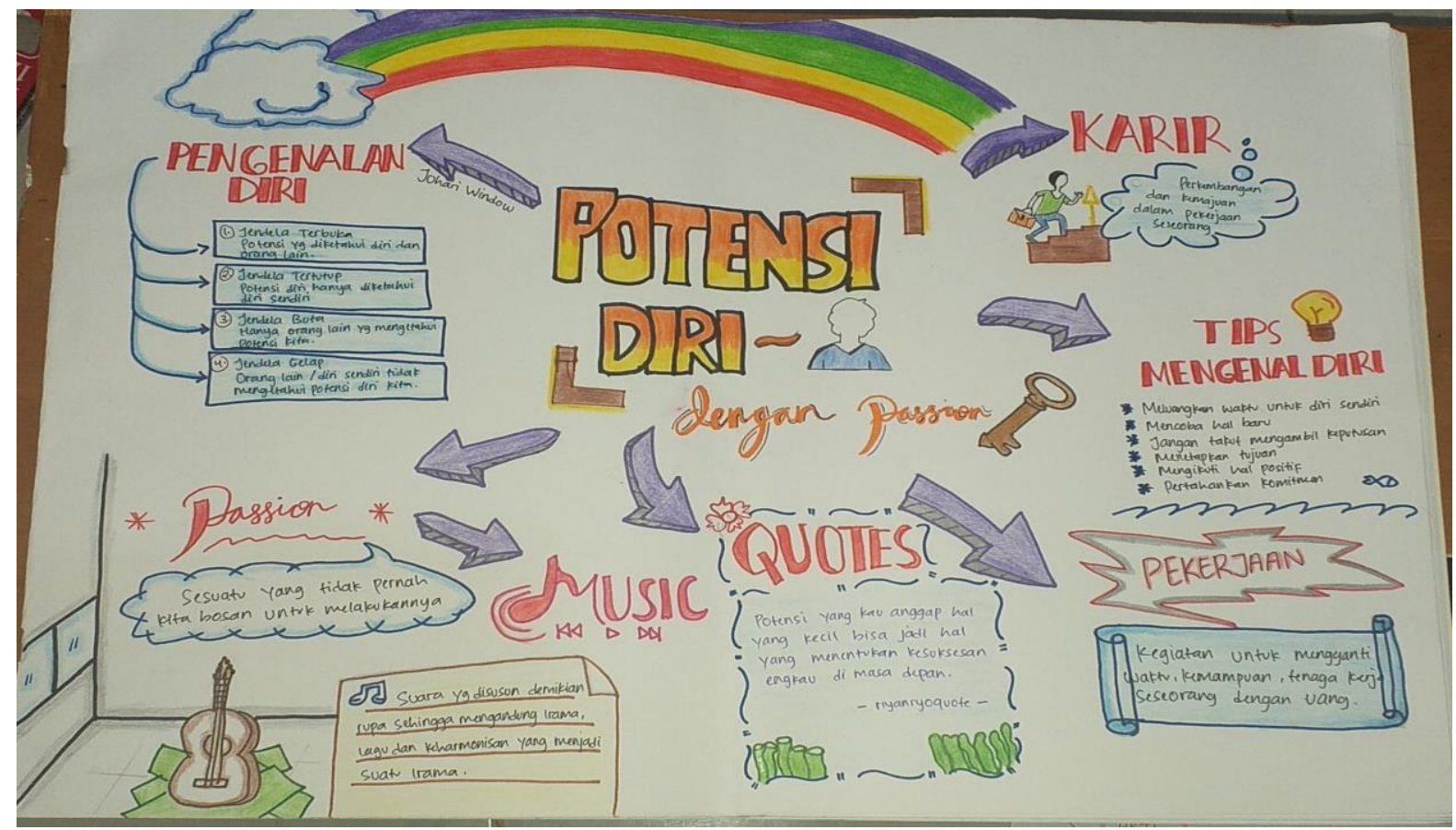

\section{Membuat Silde Presentasi dengan Link Video Youtube}

a) Pengajar menyampaikan tema dari silde presentasi yang akan dibuat Mahasiswa

b) Slide presentasi dibuat dengan Power Point

c) Slide presentasi dengan menampilkan kata kunci saja dan penjelasan materinya dapat disampaikan dengan video/audio disertai dengan menampilkan gambar yang sesuai dengan narasi dari setiap slide. Di transfer menjadi video(MPEG-4 Video) dan di upload di Youtube.

IV. Quiz Esai

Jawaban mahasiswa dengan menggunakan metode Mind Map yaitu Mahasiswa menstrukturkan pikiran/jawabannya.

\section{PENUTUP}

\section{Simpulan}

Berdasarkan hasil pengujian dan pembahasan yang telah dilakukan dapat ditarik kesimpulan sebagai berikut:

a) Penggunaan multimedia dalam pembuatan konten pembelajaran e-Learning sangat bermanfaat

b) Model pembelajaran dengan konsep mind map dalam sistem e-Learning merupakan sebuah terobosan baru dibidang pengajaran dan pembelajaran, karena mampu meminimalkan perbedaan cara mengajar dan materi, sehingga memberikan standar kulitas pembelajaran yang lebih konsisten.

c) Sistem e-Learning adalah mutlak diperlukan untuk mengantisipasi perkembangan jaman dengan dukungan teknologi informasi dimana semua menuju ke era digital, baik mekanisme maupun konten.

\section{Saran}


1. Penerapan konsep pembelajaran mind map dalam sistem e-learning pada pembelajaran mata kuliah akhirnya dapat menghemat biaya pengajaran dan pelatihan, akan tetapi memerlukan investasi yang sangat besar pada permulaanya, sehingga jika tidak dikelola dengan baik akan mengakibatkan kerugian yang besar

2. Pemanfaatan metode pembalajaran mind map dalam e-learning membutuhkan budaya belajar mandiri dan kebiasaan untuk belajar bagi para dosen. Kurangnya interaksi antar dosen dengan mahasiswa atau bahkan antar mahasiwa itu sendiri bisa memperlambat terbentuknya budaya atau values dalam proses belajar dan mengajar.

3. Sarana untuk menerapkan metode mind map dalam e-learning ini sangat positif sekali untuk dikembangkan dengan layanan yang lain seperti media komunikasi dalam format video atau voice.

\section{DAFTAR RUJUKAN}

Elyas, A. H. (2018). Penggunaan Model Pembelajaran E-Learning Dalam Meningkatkan Kualitas Pembelajaran. Warta Dharmawangsa, (56).

Handayani, L., \& Ristrini, R. (2010). Pengaruh Model Pembelajaran Kesehatan Menggunakan Multimedia Terhadap Perubahan Pengetahuan Dan Sikap Siswa Sltp Terkait Faktor Risiko Penyakit Jantung Koroner.Buletin Penelitian Sistem Kesehatan, 13(4), 21313.

Hede, T., \& Hede, A. (2002, July). Multimedia effects on learning: Design implications of an integrated model. In Untangling the web: Establishing learning links. Proceedings ASET Conference (pp. 7-10).

Heinich, R., Molenda, M., Russel, J. D., \& Smaldino, S. E. (2002). Instructional media and technology for learning. Pearson Education Ltd.

Mutia, I., \& LEONARD, L. (2015). Kajian penerapan e-learning dalam proses pembelajaran di perguruan tinggi. Faktor Exacta, 6(4), 278-289.

Tafiardi. 2005. Meningkatkan Mutu Pendidikan Melalui E-Learning. Jurnal PendidikanPenabur - No.04/ Th.IV/ Juli 2005

Herdin. 2017. Tujuh Rahasia Mind Map, PT Elex Media Komputindo, Jakarta

Buzan, Tony. 2008. Buku Pintar Mind Map. Jakarta: PT. Gramedia Pusaka Utama.

Shoimin, Aris. 2014. Model Pembelajaran Inovatif dalam Kurikulum 2013. Jakarta: Ar-Ruzz Media.

Swadarma, Doni. 2013. Penerapan Mind Mapping dalam Kurikulum Pembelajaran. Jakarta: PT. Elex Media Kompetindo.

http://resources.intenseschool.com/introduction-to-computer-assisted-learning-cal/ 